\title{
ANALYSIS OF POPULATION MORTALITY CAUSES IN REPUBLIC OF NORTH OSSETIA ALANIA
}

\author{
L. Gurieva \\ Financial University under the Government of the Russian Federation. \\ Vladikavkaz, Russian Federation \\ science-almanac@mail.ru
}

The article is dedicated to research of the most significant death reasons of the Republic of North Ossetia-Alaniya population, to which one can refer high infant mortality and death growth of oncological diseases. Particularly, it is educed that infant mortality grew in 1,4 times for 2000-2014 in the region. It is shown that infants before one year old die from two groups of reasons in North Ossetia: from congenital anomalies, from individual conditions, appearing in perinatal period, and from the health state of mother, breeding a child. Fixed level is observed according to the first group of indice, but the index of "infant mortality from separate states, appearing in perinatal period" grew in 2,4 times in 2000-1014.

The analysis of adult population mortality educed high and steadily growing intensity of deaths from morbid growths. Death intensity from this reason is generally high in Russian and in all regions of the NorthCaucasian federal district, however, the number of registered sick people with firstly made diagnosis of malignant neoplasms grew to $17,1 \%$ for ten years in the Republic of North Ossetia-Alaniya. The conclusion is made about the fact that decrease of mortality level continues to be priority aim of socioeconomic policy of Russian Federation and its regions.

Key words: population mortality, infant mortality, reasons classes of population mortality.

A lot of natural and social factors influence on lifetime and level of population mortality.One can speak about two factor groups from the point of view of system analysis: endogenous, generated by internal development of a human organism, and exogenous, connected with actions of external environment.Considering that the first group represents an objective sphere of medicine, the second group factors become the object of socioeconomic policy of population mortality decrease, to which it is customary to refer: health authorities efficiency, population living standard, society hygiene level, ecological environment influence.Notice that in "pure form" none factor can work - people live in naturally-social environment, where their live depends on the whole complexof factors. One can speak about only degree influence alteration to population mortality of some or other factor in the space and time.Research of dead peopledistribution by themedical death reason, in other words according to the last diagnosis of the dead person,takes an important place in the modern mortality analysis. The death reason is determined on the basis of medical worker conclusion according to the disease, casualty or any other external influence, served as the death reason. Not always it can be pointed to the one reason of death, that is why the World Health Organization (WHO) recommends toindicate all the diseases and traumas, which brought to or contributed to death.

Writings in the medical death certificates, composed by the doctor according to the disease, casualty, murder, suicide and any other external influence, served as the reason of death are appeared to be the information source about death reasons. Such writings serve as the basis for death reason indication in the death statements. The reason, according to which the death occurs, is confirmed by the corresponding medical organ or doctor. At thatthe modern death reasons statistics is based on emphasizing of one, leading, or initial death reason. In recent years one can observe the decrease of population death level in the Republic of North Ossetia-Alaniya practically on all basic classes of 
death reasons with some waves according to the years that can be estimated as the positive tendency and the most important socioeconomic result(table1).

Table1

\section{Population mortality dynamics in the Republic of North Ossetia-Alaniya according to the basic reason classes of death in 2000-2014 \\ (the number of death people per 100000 of population)}

\begin{tabular}{|c|c|c|c|c|c|c|c|c|}
\hline & \multirow[b]{2}{*}{$\begin{array}{l}\text { Died from } \\
\text { all reasons } \\
\text { of death }\end{array}$} & \multicolumn{7}{|c|}{ From them by reasons of death } \\
\hline & & $\begin{array}{l}\text { someinfec } \\
\text { tious and } \\
\text { parasitic } \\
\text { diseases }\end{array}$ & $\begin{array}{l}\text { From } \\
\text { themtub } \\
\text { erculosi } \\
\mathrm{s}\end{array}$ & $\begin{array}{l}\text { morbidg } \\
\text { rowth }\end{array}$ & $\begin{array}{l}\text { circulatory } \\
\text { system } \\
\text { diseases }\end{array}$ & $\begin{array}{l}\text { respirator } \\
\text { ydiseases }\end{array}$ & $\begin{array}{l}\text { Digestion } \\
\text { diseases }\end{array}$ & $\begin{array}{l}\text { External } \\
\text { reasons } \\
\text { of death }\end{array}$ \\
\hline 2000 & 1234,1 & 23,9 & 18,5 & 158,1 & 741,5 & 41,3 & 69,2 & 123,8 \\
\hline 2005 & 1230,4 & 22,7 & 19,6 & 160,7 & 798,0 & 25,7 & 80,0 & 93,3 \\
\hline 2010 & 1088,0 & 16,9 & 13,9 & 158,3 & 698,3 & 26,8 & 70,2 & 76,0 \\
\hline 2014 & 1072,1 & 11,2 & 9,1 & 166,3 & 687,6 & 25,3 & 60,9 & 63,6 \\
\hline
\end{tabular}

Source:Statistical yearbook of RNO-Alaniya. Statistics digest. Vladikavkaz 2015. P. 50. http://osetstat.gks.ru.

Table2

\section{Infant mortality in the Republic of North Ossetia-Alaniya according to the basic classes of death reasons in $2000-2014$}

\begin{tabular}{|c|c|c|c|c|}
\hline & 2000 & 2005 & 2010 & 2014 \\
\hline \multicolumn{5}{|l|}{ General number of people } \\
\hline Died in the age from 1 from all reasons & 84 & 70 & 77 & 116 \\
\hline From some infectious and parasitic diseases & 17 & 2 & 4 & 2 \\
\hline From respiratory diseases & 10 & 1 & 7 & 9 \\
\hline From digestive organ diseases & 2 & 1 & 6 & 2 \\
\hline $\begin{array}{l}\text { From congenital anomalies (malformations), deformations and } \\
\text { chromosomal defections }\end{array}$ & 20 & 20 & 19 & 19 \\
\hline From individual conditions, occurring in perinatal period & 31 & 41 & 34 & 75 \\
\hline From external death reasons & 3 & 1 & 1 & 5 \\
\hline \multicolumn{5}{|l|}{ Per 10000 of new born } \\
\hline Died in the age of 1 from all the reasons & 116,9 & 88,7 & 75,0 & 107,5 \\
\hline From some infectious and parasitic diseases & 23,7 & 2,5 & 3,9 & 1,9 \\
\hline From respiratory diseases & 13,9 & 1,3 & 6,8 & 8,3 \\
\hline From digestive organ diseases & 2,8 & 1,3 & 5,8 & 1,9 \\
\hline $\begin{array}{l}\text { From congenital anomalies (malformations), deformations and } \\
\text { chromosomal defections }\end{array}$ & 27,9 & 25,3 & 18,5 & 17,6 \\
\hline From individual conditions, occurring in perinatal period & 43,2 & 51,9 & 33,1 & 69,5 \\
\hline From external death reasons & 4,2 & 1,3 & 1,0 & 4,6 \\
\hline
\end{tabular}

Source:Statistical yearbook of RNO-Alaniya. Statistics digest. Vladikavkaz 2015. P. 50. http://osetstat.gks.ru.

As it can be seen from the table 1, for the analyzed period mortality decrease occurs with various tempos according to such basic class reasons as: circulatory system 
diseases, some infectious and parasitic diseases, tuberculosis, external reasons of death, respiratory diseases, and digestion diseases.These reasons classes are strongly depended on the population living conditions, from its mode of life, society hygiene culture; in major degree they are determined by behavioral factors, people' attitude to their health.It is worth stopping at the analysis of infant mortality, which grew in the Republic of North Ossetia-Alaniya for the analyzed period in 1,4 times: from 84 of children in 2000 to 116 of children in 2014 (table 2).

As statistical data analysis shows, infants to one year in North Ossetia generally die from two groups of reasons: from congenital anomalies, from individual conditions occurring in perinatal period, and from health condition of the mother, breeding a baby.As one can see from the table 2, the index "infant death from separate conditions, appearing in perinatal period" in 2014 grew in 2,4 times in the Republic of North Ossetia-Alaniya in comparison with 2000 . This fact testifies about necessity of intensive development system of diagnosticand general health institutions for the pregnant women with modern medical technologies and apparatus implementation, from one side, from the other side, - about necessity of family planning system advance, as infants mortality, depended on the mother health state, appearing in perinatal period, significantly depends on the woman way of life in the pregnancy period. According to the other mostly widespread reason of infant mortality, mainly connected with life social conditions and health service development, congenital anomalies - the level of infants' mortality has tendency to constant decrease, though intensity of its influence remains to be rather high.Under the mortality analysis of adult population in the Republic of North Ossetia-Alaniya high and steadily growing death intensity from morbid growthsespecially disquiets. Mortality intensity from this reason is generally high in Russia and in all regions of North-Caucasian federal region (table3).

As one can see from the data of table 3, mortality from morbid growths stays at the second place, after the circulatory systemdiseases in all regions of North-Caucasus.

Table3

Mortality according to basic classes of death reasons in Russian Federation and regions of North Caucasus federal district in 2014 (the number of died people per 100000 of population)

\begin{tabular}{|l|l|l|l|l|l|l|l|l|}
\hline & \multirow{2}{*}{$\begin{array}{l}\text { Died } \\
\text { from all } \\
\text { reason } \\
\text { of death }\end{array}$} & $\begin{array}{l}\text { From them by reasons of death } \\
\text { infectiou } \\
\text { s and } \\
\text { parasitic } \\
\text { diseases }\end{array}$ & $\begin{array}{l}\text { From } \\
\text { them } \\
\text { tubercu } \\
\text { losis }\end{array}$ & $\begin{array}{l}\text { Sowths } \\
\text { morbidg }\end{array}$ & $\begin{array}{l}\text { circulatory } \\
\text { system } \\
\text { diseases }\end{array}$ & $\begin{array}{l}\text { respirat } \\
\text { orysyst } \\
\text { em } \\
\text { disease } \\
\text { s }\end{array}$ & $\begin{array}{l}\text { digestiv } \\
\text { eorgan } \\
\text { s } \\
\text { disease } \\
\text { s }\end{array}$ & $\begin{array}{l}\text { Extern } \\
\text { al } \\
\text { reason } \\
\text { of } \\
\text { death }\end{array}$ \\
\hline $\begin{array}{l}\text { Russian } \\
\text { Federation }\end{array}$ & 1305,8 & 22,3 & 10,0 & 201,9 & 653,9 & 54,5 & 67,2 & 129,9 \\
\hline $\begin{array}{l}\text { North- } \\
\text { CaucasianF } \\
\text { D }\end{array}$ & 804,8 & 8,8 & 6,0 & 118,2 & 433,0 & 34,4 & 34,7 & 59,5 \\
\hline Dagestan & 553,9 & 7,0 & 4,3 & 70,3 & 227,3 & 60,6 & 22,0 & 49,6 \\
\hline Ingooshetia & 345,9 & 7,9 & 4,6 & 60,2 & 167,9 & 7,9 & 5,9 & 28,1 \\
\hline Kabardino- & 880,8 & 15,8 & 11,8 & 135,4 & 523,6 & 30,4 & 46,0 & 64,6 \\
\hline
\end{tabular}




\begin{tabular}{|l|l|l|l|l|l|l|l|l|}
\hline Balkaria & & & & & & & & \\
\hline $\begin{array}{l}\text { Karachai- } \\
\text { CircassianRe } \\
\text { public }\end{array}$ & 969,9 & 6,6 & 2,3 & 144,0 & 547,0 & 31,5 & 40,5 & 84,1 \\
\hline RNO-Alaniya & 1072,1 & 11,2 & 9,1 & 166,3 & 687,6 & 25,3 & 60,9 & 63,6 \\
\hline Chechnia & 505,3 & 7,4 & 4,6 & 82,9 & 281,6 & 8,2 & 11,2 & 22,4 \\
\hline $\begin{array}{l}\text { StavropolTer } \\
\text { ritory }\end{array}$ & 1174,0 & 9,2 & 6,8 & 173,9 & 657,8 & 27,5 & 53,4 & 86,5 \\
\hline
\end{tabular}

Source:Statistical yearbook of RNO-Alaniya. Statistics digest. Vladikavkaz 2015. P. 50. http://osetstat.gks.ru.

Alongside with that intensity of deaths by this reason is strongly differentiated according to the regions. The most part of dead people in the view to one hundred thousand people is fixed in Stavropol Territory - 173,9 of cases. The minimal index is marked in Ingooshetia- 60,2 of cases. The given coefficient is very high in the North Ossetia - 166,3 of cases.In years to come the mortality from oncology in the North Caucasus, most probably, will grow, as, for instance, the number of oncosick people grows rather intensively in the North Ossetia. For the last ten years the number of registered sick people with for the first time in life registered diagnosis of malignant neoplasms increased on 341 person or on $17,1 \%$. Accordingly the general number of patients with malignant neoplasms grew that is obviously can be seen from the data of the table 4 .

Table4

\section{Contingents of patients with malignant neoplasms in Russian federation and regions of the North-Caucasus federal district in 2005-2014}

\begin{tabular}{|l|l|l|l|l|l|l|}
\hline & \multicolumn{3}{l}{ General number of people } & \multicolumn{4}{l|}{ Per 100000 of population } \\
\cline { 2 - 7 } & 2005 & 2010 & 2014 & 2005 & 2010 & 2014 \\
\hline Russian Federation & 2386766 & 2794189 & 3098855 & 1679,8 & 1955,8 & 2252,7 \\
\hline North-Caucasian FD & 86148 & 121048 & 135365 & 1092,6 & 1282,4 & 1406,5 \\
\hline Dagestan & 12920 & 17064 & 21840 & 479,8 & 585,5 & 733,6 \\
\hline Ingooshetia & 1454 & 2827 & 3903 & 348,4 & 682,0 & 851,3 \\
\hline Kabardino-Balkaria & 10837 & 12347 & 14182 & 1251,2 & 1436,0 & 1649,9 \\
\hline Karachai-CircassianRepublic & 5123 & 5527 & 7070 & 1127,2 & 1157,7 & 1506,0 \\
\hline RNO-Alaniya & 9993 & 12263 & 14731 & 1413,6 & 1721,2 & 2090,6 \\
\hline Chechnia & $\ldots$ & 16661 & 14431 & $\ldots$ & 1306,6 & 1062,4 \\
\hline StavropolTerritory & & & & & & \\
\hline
\end{tabular}

Source:Health service in Russia. Statistics digest. M.: 2006, 2011 and 2015. http://www.gks.ru 
Also the fact is alarm that for the period of 2005-2014 the number of sick people with malignant neoplasms, registered in general health organizations, grew in the Republic of the North Ossetia-Alaniya on 4,7 thous. people, or on $147,4 \%$. In the regions of the North-Caucasus federal district oncosickness rateprogresses with higher tempos in Stavropol region and in Ingooshetia. However, the general coefficient of oncosickness in 2,5 times lower, than in the Republic of North Ossetia-Alaniya.For the last 25-30 years in all economically developed countries mortality steadied at the rather low level. It stays to be intensivedespite on mortality decrease tendency in Russia and, also in North Ossetia. Consequently, mortality level decrease continues to stay the top target of socioeconomic policy of Russian Federation and its regions.

\section{Лumepamypa}

1. Гуриева Л.К. Новые подходы к инновационному развитию регионов // Гуманитарные и социальные науки. 2013. № 5.

2. Туаева Л.А. Взаимосвязь между медико-демографической ситуацией и социально-экономическим положением в Республике Северная ОсетияАлания//TerraEconomicus. 2013. Т. 11. № 3-3.

3. Туаева Л.А., Сугарова И.В. Эффрективность расходования средств на систему здравоохранения// TerraEconomicus. 2013. Т. 11. № 3-3.

4. Gurieva L.K., Zangiev I.E., Dzatseev D.R. Moral aspects of liberal economy formation in russia // Гуманитарныеисоциально-экономическиенауки. 2016. № 1 (86).

5. Gurieva L.K. New strategic approach to the innovative development of regions // НаучныйальманахстранПричерноморья. 2016. № 2 (6).

6. Gurieva L.K., Dzhioev A.V. Sustainable development of the russian economy // НаучныйальманахстранПричерноморья. 2016. № 2 (6).

7. Shkurkin D.V., Shestopal S.S., Gurieva L.K., Blaginin V.A., Gurianov P.A. Basic characteristics of an intensive type of the reproduction process in the regional economy//International Review of Management and Marketing. 2016. T. 6. № S1.

\section{References}

1. GurievaL.K. New approaches to the innovative development of the regions // Humanitarian and social sciences. 2013. No 5.

2. TuaevaL.A.Interconnection between medical-demographic situation and socioeconomic position in the Republic of North Ossetia-Alaniya//Terra Economicus. 2013. T. 11. No 3-3.

3. Tuaeva L.A.., Sugaroval.V.Means expenditure efficiency to the health services // Terra Economicus. 2013. T. 11. No 3-3.

4. Gurieva L.K., Zangiev I.E., Dzatseev D.R. Moral aspects of liberal economy formation in Russia // Humanitarian and socioeconomic sciences. 2016. No1 (86).

5. Gurieva L.K. New strategic approach to the innovative development of regions // Science almanac of Black sea region countries. 2016. No 2 (6).

6. Gurieva L.K., Dzhioev A.V. Sustainable development of the Russian economy // Science almanac of Black sea region countries. 2016. No 2 (6).

7. Shkurkin D.V., Shestopal S.S., Gurieva L.K., Blaginin V.A., Gurianov P.A. Basic characteristics of an intensive type of the reproduction process in the regional economy//International Review of Management and Marketing. 2016. Vol. 6. No S1. 